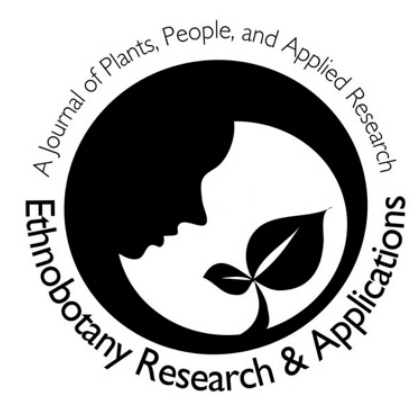

\title{
Medicinal plants used to treat acute digestive system problems in the region of Fez-Meknes in Morocco: An
} ethnopharmacological

\author{
survey
}

\author{
Imane Es-Safi, Hamza Mechchate, Amal Amaghnouje, \\ Fatima Zahra Jawhari, Amina Bari, Pierfrancesco Cerruti, \\ Maurizio Avella, Andriy Grafov, Dalila Bousta
}

\section{Research}

\begin{abstract}
Background: In Morocco, acute digestive system problems appear to be a famous daily ill which the most population deal with using medicinal plants. This work aims to inventory the plants used to deal with acute digestive system problems in the region of Fez-Meknes.
\end{abstract}

Methods: A survey was carried out by means of a semi-structured questionnaire. A total of 423 interviews (108 of them are traditional health practitioners) were conducted. Botanical information about identified plants was carefully collected. Data were analyzed through the relative frequency of citation (RFC).

Results: All respondents informed about the effectiveness of the medicinal plants and confirmed successful multiple uses of them. In total, 50 species belonging to 23 families were reported. The mostreported plant families were Lamiaceae (12 species), Apiaceae (10 species), Fabaceae, and Asteraceae (5 species). The most frequently used plants to treat digestive system acute problems based on their RFC values were: Foeniculum vulgare (8.58), Carum carvi (5.11) Glycyrrhiza glabra (4.56) Ammondaucus leucotrichus, Trigonella foenum-graecum, (4.20), Coriandrum sativum (4.01). The use of medicinal plants in the acute digestive system problems, according to the interviewed people, concerned six categories: Acute ache, digestion problems, intestinal comfort, bloating, diarrhea, and constipation.

\section{Correspondence \\ Imane Es-Safi ${ }^{1}$, Hamza Mechchate ${ }^{1^{*}}$, Amal Amaghnouje $^{1}$, Fatima zahra Jawhari', Amina Bari $^{1}$, Pierfrancesco Cerruti ${ }^{2}$, Maurizio Avella ${ }^{3}$, Andriy Grafov ${ }^{4}$, Dalila Bousta ${ }^{1}$ \\ ${ }^{1}$ Laboratory of Biotechnology, Environment, Agrifood, and Health, University of Sidi Mohamed Ben Abdellah, FSDM-Fez, Morocco \\ 'Institute for Polymers, Composites, and Biomaterials (IPCB-CNR), Naples, Italy \\ ${ }^{3}$ Institute for Chemistry and Technology of Polymers (ICTP-CNR), Naples, Italy \\ ${ }^{4}$ Laboratory of Inorganic chemistry, Department of chemistry, University of Helsinki, Finland. \\ Corresponding Author: \\ Hamza.mechchate@usmba.ac.ma \\ Ethnobotany Research \& Applications 20:25 (2020)}

Conclusion: Knowledge of medicinal plants used to treat acute digestive system problems was solid. Indeed, all the local population used medicinal plants as a first choice to deal with it. This study represents 
a useful inventory to preserve and spread this knowledge.

Keywords: Ethnopharmacological survey; Digestive system problems; Medicinal plants; Morocco; Acute ache; digestion problems; intestinal comfort; bloating, diarrhea; constipation.

\section{Background}

The use of plants for therapeutic purposes has been known since time immemorial. Ancient mythology shows a keen interest in medicinal plants to treat several diseases (Budha-Magar et al. 2020; Malinga et al. 2020; Mechchate et al. 2020). Although modern medicine is well developed almost everywhere in the world, a sizable proportion of the population in developing countries still relies on traditional practitioners and herbal medicines for their primary care (World Health Organization 2002). Morocco is a country of highly diverse flora with more than 5200 species and subspecies of vascular plants, including 900 endemic plants (Fennane and Ibn Tattou 2012). Aromatic and medicinal plants are represented by over 743 taxa belonging to 101 families and 371 genera, among which 40 taxa are endemic to Morocco (Jamaleddine et al. 2017).

The use of herbs as medicines to treat ailments of the digestive tract is widespread. In digestion, food and drink are transported in the digestive tract, broken down into small parts (called nutriments) that the body can absorb and use as energy and building blocks for cells. Digestive diseases are disorders of the digestive or gastrointestinal tract, which interfere with the digestive process that includes ingestion, propulsion, mechanical or physical digestion, chemical digestion, absorption, and defecation (ACOG 2014). Taking into consideration that disorders of the digestive system are usually closely interrelated, the medicinal plants used for treatment tend to be multipurpose and can be used for a variety of digestive symptoms and disorders (Sidhu et al. 2007). The present paper aims to identify the medicinal plants used in the region of Fez-Meknes in Morocco for acute digestive problems.

\section{Materials and Methods}

\section{Study context}

The main focus of this study is to highlight the natural alternatives that people in the Fez-Meknes region use to treat acute digestive problems according to their personal experience. Ethnopharmacological information was obtained from 423 People, 108 of them are traditional health practitioners.

\section{Study area}

The study was conducted in the Fez-Meknes region (Figure 1), which covers an area of $40,075 \mathrm{Km}^{2}$ or $5.7 \%$ of the national territory, with a population of over 4 million people. This region is located in the Plain of Saiss, halfway between the north and the south of the Kingdom of Morocco. This region includes seven provinces: Boulemane, El Hajeb, Ifrane, Moulay Yaâcoub, Sefrou, Taounate, and Taza (Monographie Générale 2015).

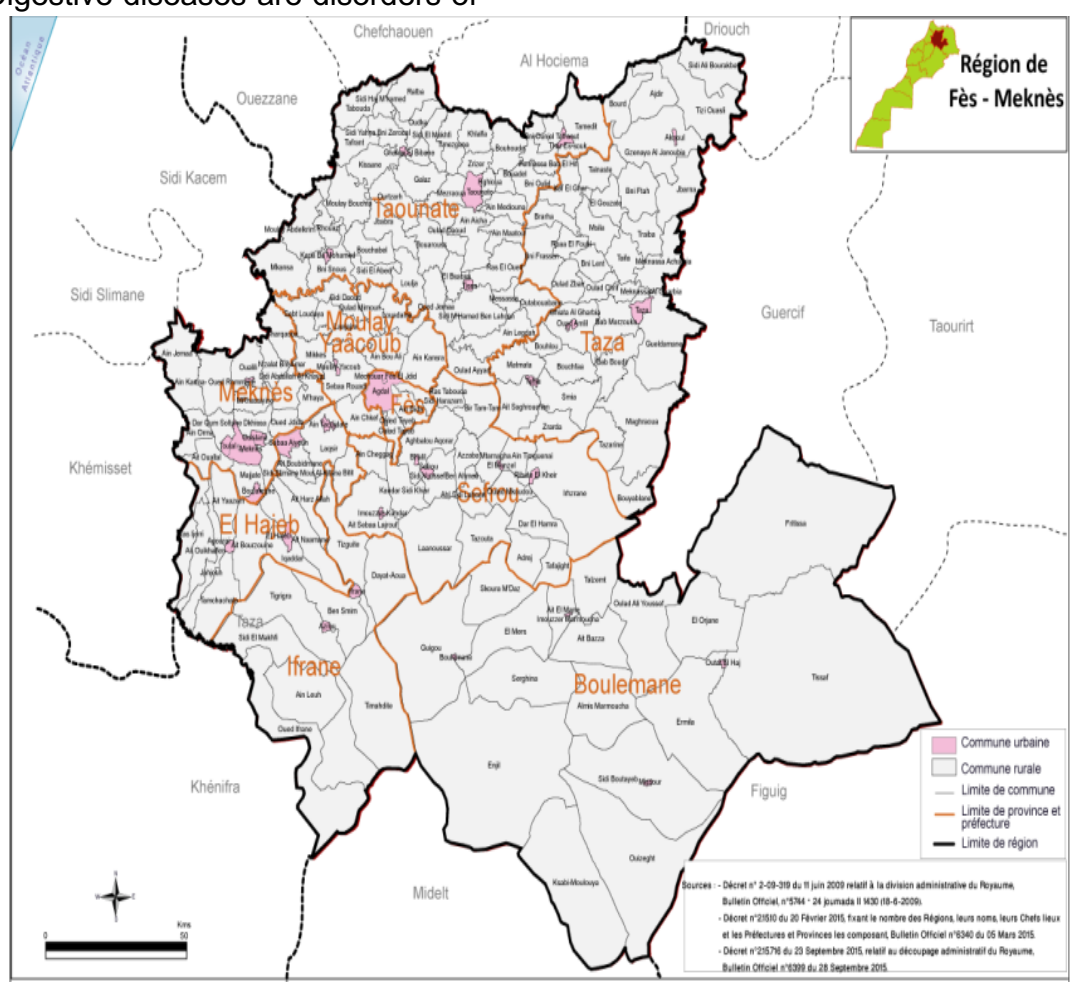

Figure 1. Map of the study area 


\section{Ethnopharmacological survey}

An Ethnopharmacological survey was conducted from November 2018 to May 2019. The data were collected through a semi-structured questionnaire (Annex A).

\section{Plant identification}

To avoid any confusion between local names and scientific names, the interviewers collected all possible knowledge on the confusing species with many samples and photos taken. Respondents were also re-consulted in especially doubtful cases till the final identification of the specie. Identification of botanical names was undertaken in collaboration with Professor Amina Bari (Botanist) and following the "FLORE PRATIQUE DU MAROC" (Practical Flora of Morocco) (Fennane et al. 1999). Voucher specimens of each plant have been deposited at the herbarium of the Laboratory of Environment in the Faculty of Sciences Dhar el Mahraz Fez.

\section{Data analysis}

\section{Relative frequency of citations}

The relative frequency of citation shows the local importance of each species, and it's obtained by dividing the number of informants, who mention the use of the species, also known as the Frequency Citation (FC), by the number of informants participating in the survey $(\mathrm{N})$ (Tardío and Pardo-deSantayana 2008).

$$
\mathrm{RFC}=\mathrm{FCIN}(0<\mathrm{RFC}<1)
$$

\section{Statistical analysis}

Raw data entries were carried out using Microsoft Excel 2016 for windows. Frequencies were calculated with JASP statistics version 0.9.2.0 for windows, and figures were made with GraphPad Prism version 6.01 for windows.

\section{Results and Discussion}

Socio-demographic profile of the interviewers

Table 1 displays the socio-demographic profile of the interviewers. Among the 423 People interviewed, 147 were men $(45,37 \%)$ and 177 women $(54,63 \%)$. All of them use medicinal plants to treat acute digestive system problems. Their age varied between 18 and 89 years. The interviewers were arbitrarily divided into four age groups: $<20$ years, 20-40years, 40-60 years, and $>60$ years (respectively, 11, 145, 121, and 47 persons). For their educational level, $36,11 \%$ were illiterate, while $25,62 \%$ attended at least primary school. The rest were either secondary $(21,91 \%)$ or university level $(16,36 \%)$ of education.
Table 1. Sociodemographic profile of the diabetic patients

\begin{tabular}{llll}
\hline Variable & Subgroup & Number & $\begin{array}{l}\text { Percentage } \\
(\%)\end{array}$ \\
\hline Sex & Male & 147 & 45,37 \\
& Female & 177 & 54,63 \\
Age & 20 years & 11 & 3,40 \\
& $20-40$ years & 145 & 44,75 \\
& $40-60$ years & 121 & 37,35 \\
& $>60$ years & 47 & 14,50 \\
Education & Illiterate & 117 & 36,11 \\
level & Primary & 83 & 25,62 \\
& Secondary & 71 & 21,91 \\
& University & 53 & 16,36 \\
\hline
\end{tabular}

\section{Sources of information}

Their sources of information varied between other people's experiences $(48,5 \%)$, traditional health practitioners $(45,5 \%)$, virtues explored by themselves $(3 \%)$, the internet $(2.4 \%)$, and finally books $(0.6 \%)$, but their most important source was other experiences with $48,5 \%$.

Only a few people count on literature and research to look for their information. Their main source was either the other experiences or traditional health practitioners. This is related to the specialties of our society, when a plant or a formulation is effective, the person using it recommends it to his family and friends, and this how medicinal plant knowledge is spread.

\section{Reasons to use medicinal plants}

All interviewed persons noted that medicinal plants were effective and confirmed that by their multiple uses. In addition to their availability, low cost, and almost no side effects.

Inventory of selected medicinal plants and floristic analysis

A total of 50 medicinal plants species belonging to 23 families were recorded. The plants were listed in alphabetical order by families (Table 2). Information such as the vernacular name of plant species, citation, frequency of citations (RFC), parts used, state of the plants, formulation, and preparation, utilization is provided for each species. Families with the most reported plant species were Lamiaceae (12 species), Apiaceae (10 species), Fabaceae, and Asteraceae (5 species) (Figure 2).

The Lamiaceae family is one of the most prominent plant families among flowering plants, with more than 7000 species grouped in 236 genera. This family encompasses many bioactive molecules, which make it an important family in the biological and medical applications (Uritu et al. 2018). 
Table 2. Inventory of the medicinal plants used for the treatment of digestif system acute ache in the Fez-Meknes region, Morocco

\begin{tabular}{|c|c|c|c|c|c|c|}
\hline $\begin{array}{c}\text { Name of plants } \\
\text { Voucher number }\end{array}$ & $\begin{array}{l}\text { Vernacular } \\
\text { name }\end{array}$ & Citation & RFC(\%) & $\begin{array}{l}\text { Part used } / \\
\text { State }\end{array}$ & Formulation, and preparation & Used for \\
\hline \multicolumn{7}{|l|}{ Anacardiaceae } \\
\hline $\begin{array}{l}\text { Pistacia lentiscus L. } \\
\text { BPRN81 }\end{array}$ & Drou & 3 & 0.55 & L/F or D & $\begin{array}{c}\text { Decoction, handful quantity in } 1 \mathrm{~L} \text { of } \\
\text { water, }\end{array}$ & $\begin{array}{l}\text { Acute ache; digestion } \\
\text { problems }\end{array}$ \\
\hline \multicolumn{7}{|l|}{ Apiaceae } \\
\hline $\begin{array}{l}\text { Ammi visnaga (L.) Lam } \\
\text { BPRN20 }\end{array}$ & Bechnikha & 5 & 0.91 & $\begin{array}{l}\text { Umbel/F or } \\
\text { D }\end{array}$ & $\begin{array}{c}\text { Decoction, handful quantity in } 1 \mathrm{~L} \text { of } \\
\text { water }\end{array}$ & $\begin{array}{l}\text { Acute ache; digestion } \\
\text { problems }\end{array}$ \\
\hline $\begin{array}{l}\text { Ammondaucus leucotrichus } \\
\text { Coss. \& Durieu }\end{array}$ & Kamoun Essoufi & 23 & 4.20 & $S / D$ & $\begin{array}{l}\text { Decoction of powder, handful quantity } \\
\text { in } 1 \mathrm{~L} \text { of water }\end{array}$ & $\begin{array}{l}\text { Acute ache; digestion } \\
\text { problems; bloating }\end{array}$ \\
\hline \multicolumn{7}{|l|}{ BPRN70 } \\
\hline $\begin{array}{l}\text { Apium graveolens } \mathrm{L} . \\
\text { BPRN25 }\end{array}$ & Krafess & 3 & 0.55 & $\mathrm{AP} / \mathrm{F}$ & Juice, variable quantity mix with water & $\begin{array}{l}\text { Acute ache; digestion } \\
\text { problems }\end{array}$ \\
\hline $\begin{array}{l}\text { Carum ammoïdes Benth \& } \\
\text { Hook }\end{array}$ & Nûnkha & 3 & 0.55 & AP/D & Decoction, handful quantity in $1 \mathrm{~L}$ & Acute ache \\
\hline \multicolumn{7}{|l|}{ BPRN89 } \\
\hline $\begin{array}{l}\text { Carum carvi L. } \\
\text { BPRN15 }\end{array}$ & Karwiya & 28 & 5.11 & $S / D$ & Powder, 1 Tablespoon & $\begin{array}{l}\text { Acute ache; digestion } \\
\text { problems; bloating }\end{array}$ \\
\hline $\begin{array}{l}\text { Coriandrum sativum } \mathrm{L} . \\
\text { BPRN28 }\end{array}$ & Kassbour & 22 & 4.01 & $S / D$ & Powder, 1 Tablespoon & $\begin{array}{l}\text { Acute ache; digestion } \\
\text { problems; bloating }\end{array}$ \\
\hline $\begin{array}{l}\text { Cumun cyminum L. } \\
\text { BPRN72 }\end{array}$ & Kamoun & 13 & 2.37 & $S / D$ & Powder, 1 Tablespoon & $\begin{array}{l}\text { Acute ache; digestion } \\
\text { problems; bloating and } \\
\text { Diarrhea }\end{array}$ \\
\hline $\begin{array}{l}\text { Foeniculum vulgare Mill. } \\
\text { BPRN18 }\end{array}$ & Hebet hlawa & 47 & 8.58 & $S / D$ & Powder, 1 Tablespoon & $\begin{array}{l}\text { Acute ache; digestion } \\
\text { problems; intestinal comfort; } \\
\text { bloating }\end{array}$ \\
\hline $\begin{array}{l}\text { Petroselinum crispum Mill. } \\
\text { BPRN30 }\end{array}$ & Maadnouss & 4 & 0.73 & AP/F & Juice, variable quantity mix with water & $\begin{array}{l}\text { Acute ache; against } \\
\text { constipation }\end{array}$ \\
\hline $\begin{array}{l}\text { Pimpinella anisum L. } \\
\text { BPRN73 }\end{array}$ & Nafea & 19 & 3.47 & $S / D$ & Powder, 1 Tablespoon & $\begin{array}{l}\text { Acute ache; digestion } \\
\text { problems; bloating, }\end{array}$ \\
\hline \multicolumn{7}{|l|}{ Aristolochiaceae } \\
\hline $\begin{array}{l}\text { Aristolochia longa L. } \\
\text { BPRN85 }\end{array}$ & Berraztam & 3 & 0.55 & $\mathrm{R} / \mathrm{D}$ & $\begin{array}{l}\text { Decoction of powder handful quantity } \\
\text { in } 1 \mathrm{~L}\end{array}$ & $\begin{array}{l}\text { Acute ache; digestion } \\
\text { problems; }\end{array}$ \\
\hline \multicolumn{7}{|l|}{ Asteraceae } \\
\hline $\begin{array}{l}\text { Artemisia absinthium L. } \\
\text { BPRN46 }\end{array}$ & Chiba & 4 & 0.73 & $\mathrm{AP} / \mathrm{F}$ or $\mathrm{D}$ & $\begin{array}{l}\text { Decoction, handful quantity in } 1 \mathrm{~L} \text { of } \\
\text { water }\end{array}$ & $\begin{array}{l}\text { Digestion problems; } \\
\text { intestinal comfort }\end{array}$ \\
\hline
\end{tabular}




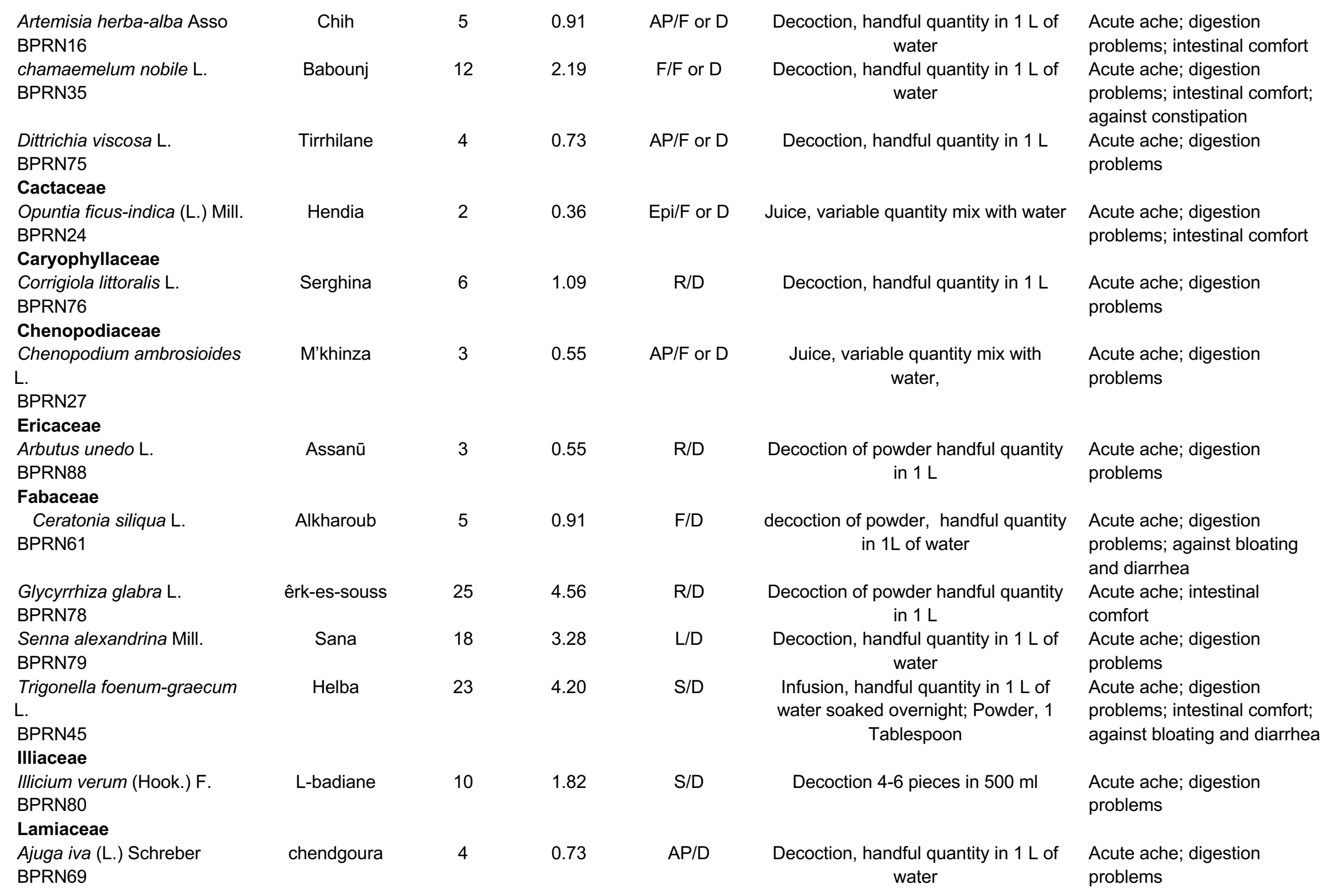




\begin{tabular}{|c|c|c|c|c|c|c|}
\hline $\begin{array}{l}\text { Lavandula angustifolia (P.) } \\
\text { Mill }\end{array}$ & l'khezama & 21 & 3.83 & $A P / F$ or $D$ & $\begin{array}{l}\text { Decoction, handful quantity in } 1 \mathrm{~L} \text { of } \\
\text { water }\end{array}$ & $\begin{array}{l}\text { Acute ache; digestion } \\
\text { problems, intestinal comfort }\end{array}$ \\
\hline \multicolumn{7}{|l|}{ BPRN82 } \\
\hline $\begin{array}{l}\text { Lavandula multifida L. } \\
\text { BPRN83 }\end{array}$ & l'khezama & 5 & 0.91 & AP/F or D & $\begin{array}{l}\text { Decoction, handful quantity in } 1 \mathrm{~L} \text { of } \\
\text { water; hydrolates } 1 \text { cup }\end{array}$ & $\begin{array}{l}\text { Acute ache; digestion } \\
\text { problems; intestinal comfort }\end{array}$ \\
\hline $\begin{array}{l}\text { Lavandula stoechas L. } \\
\text { BPRN56 }\end{array}$ & l'khezama & 9 & 1.64 & AP/F or D & $\begin{array}{l}\text { Decoction, handful quantity in } 1 \mathrm{~L} \text { of } \\
\text { water; hydrolates } 1 \text { cup }\end{array}$ & $\begin{array}{l}\text { Acute ache; digestion } \\
\text { problems; intestinal comfort }\end{array}$ \\
\hline $\begin{array}{l}\text { Marrubium vulgare L. } \\
\text { BPRN55 }\end{array}$ & Meriwta & 4 & 0.73 & $\mathrm{AP} / \mathrm{F}$ or $\mathrm{D}$ & $\begin{array}{l}\text { Decoction, handful quantity in } 1 \mathrm{~L} \text { of } \\
\text { water; hydrolates } 1 \text { cup }\end{array}$ & $\begin{array}{l}\text { Acute ache; digestion } \\
\text { problems, }\end{array}$ \\
\hline $\begin{array}{l}\text { Mentha pulegium, L. } \\
\text { BPRN49 }\end{array}$ & Fliou & 9 & 1.64 & AP/F or D & $\begin{array}{l}\text { Decoction, handful quantity in } 1 \mathrm{~L} \text { of } \\
\text { water; hydrolates } 1 \text { cup }\end{array}$ & $\begin{array}{l}\text { Acute ache, digestion } \\
\text { problems; intestinal comfort }\end{array}$ \\
\hline $\begin{array}{l}\text { Ocimum basilicum L. } \\
\text { BPRN84 }\end{array}$ & Lehbeq & 8 & 1.46 & $L / F$ & $\begin{array}{l}\text { Decoction, handful quantity in } 1 \mathrm{~L} \text { of } \\
\text { water }\end{array}$ & Intestinal comfort \\
\hline $\begin{array}{l}\text { Origanum majorana L. } \\
\text { BPRN74 }\end{array}$ & Merdedouch & 6 & 1.09 & $\mathrm{AP} / \mathrm{F}$ or $\mathrm{D}$ & $\begin{array}{l}\text { Decoction, handful quantity in } 1 \mathrm{~L} \text { of } \\
\text { water; hydrolates } 1 \text { cup }\end{array}$ & $\begin{array}{l}\text { Acute ache; digestion } \\
\text { problems; intestinal comfort }\end{array}$ \\
\hline $\begin{array}{l}\text { Origanum compactum } \\
\text { Benth. } \\
\text { BPRN11 }\end{array}$ & zaater & 19 & 3.47 & $\mathrm{AP} / \mathrm{F}$ or $\mathrm{D}$ & $\begin{array}{l}\text { Decoction, handful quantity in } 1 \mathrm{~L} \text { of } \\
\text { water; hydrolates } 1 \text { cup }\end{array}$ & $\begin{array}{l}\text { Acute ache; digestion } \\
\text { problems; intestinal comfort }\end{array}$ \\
\hline $\begin{array}{l}\text { Rosmarinus officinalis L. } \\
\text { BPRN37 }\end{array}$ & Azir & 21 & 3.83 & $\mathrm{AP} / \mathrm{F}$ or $\mathrm{D}$ & $\begin{array}{l}\text { Decoction, handful quantity in } 1 \mathrm{~L} \text { of } \\
\text { water; hydrolates } 1 \text { cup }\end{array}$ & $\begin{array}{l}\text { Acute ache; digestion } \\
\text { problems; intestinal comfort }\end{array}$ \\
\hline $\begin{array}{l}\text { Salivia officinalis L. } \\
\text { BPRN58 }\end{array}$ & Salmia & 8 & 1.46 & $L / F$ & $\begin{array}{l}\text { Decoction, handful quantity in } 1 \mathrm{~L} \text { of } \\
\text { water; hydrolates } 1 \text { cup }\end{array}$ & $\begin{array}{l}\text { Acute ache; digestion } \\
\text { problems; intestinal comfort }\end{array}$ \\
\hline $\begin{array}{l}\text { Thymus vulgaris } \mathrm{L} \text {. } \\
\text { BPRN19 } \\
\text { Liliaceae }\end{array}$ & Ziitra & 4 & 0.73 & AP/F or D & $\begin{array}{l}\text { Decoction, handful quantity in } 1 \mathrm{~L} \text { of } \\
\text { water; hydrolates } 1 \text { cup }\end{array}$ & $\begin{array}{l}\text { Acute ache; digestion } \\
\text { problems; intestinal comfort }\end{array}$ \\
\hline $\begin{array}{l}\text { Allium cepa L. } \\
\text { BPRN43 }\end{array}$ & Bassla & 7 & 1.28 & Bulb/F & Raw 1 piece & $\begin{array}{l}\text { Acute ache; intestinal } \\
\text { comfort }\end{array}$ \\
\hline $\begin{array}{l}\text { Allium sativum } L . \\
\text { BPRN52 }\end{array}$ & Touma & 5 & 0.91 & Bulb/F & Raw 2-3 pieces & $\begin{array}{l}\text { Acute ache; digestion } \\
\text { problems; against diarrhea }\end{array}$ \\
\hline \multicolumn{7}{|l|}{ Linaceae } \\
\hline $\begin{array}{l}\text { Linum usitatissimum L. } \\
\text { BPRN57 }\end{array}$ & Zeriat el Ketan & 11 & 2.01 & $S / D$ & Powder, 1-4 Tablespoon & $\begin{array}{l}\text { Acute ache; digestion } \\
\text { problems; intestinal comfort; } \\
\text { against bloating and diarrhea }\end{array}$ \\
\hline \multicolumn{7}{|l|}{ Lythraceae } \\
\hline $\begin{array}{l}\text { Punica granatum L. } \\
\text { BPRN65 }\end{array}$ & Reman & 1 & 0.18 & Epi/D & $\begin{array}{l}\text { Decoction, handful quantity in } 1 \mathrm{~L} \text { of } \\
\text { water }\end{array}$ & $\begin{array}{l}\text { Acute ache; digestion } \\
\text { problems; against diarrhea }\end{array}$ \\
\hline
\end{tabular}




\begin{tabular}{|c|c|c|c|c|c|c|}
\hline $\begin{array}{l}\text { Myrtus communis L. } \\
\text { BPRN60 }\end{array}$ & Rihane & 19 & 3.47 & L/F or D & $\begin{array}{l}\text { Decoction, handful quantity in } 1 \mathrm{~L} \text { of } \\
\text { water }\end{array}$ & $\begin{array}{l}\text { Acute ache; digestion } \\
\text { problems, intestinal comfort; } \\
\text { against diarrhea }\end{array}$ \\
\hline \multicolumn{7}{|l|}{ Oleaceae } \\
\hline $\begin{array}{l}\text { Olea europaea L. } \\
\text { BPRN12 }\end{array}$ & Zitoune & 2 & 0.36 & L/F & $\begin{array}{l}\text { Decoction, handful quantity in } 1 \mathrm{~L} \text { of } \\
\text { water bread preparation }\end{array}$ & $\begin{array}{l}\text { Acute ache; digestion } \\
\text { problems, intestinal comfort }\end{array}$ \\
\hline \multicolumn{7}{|l|}{ Papaveraceae } \\
\hline \multicolumn{4}{|l|}{ Piperaceae } & $S / D$ & Powder, 1-2 Tablespoon & Acute ache \\
\hline $\begin{array}{l}\text { Piper cubeba (L.) F. } \\
\text { BPRN86 } \\
\text { Ranunculaceae }\end{array}$ & Alkabbaba & 21 & 3.83 & $S / D$ & Powder 1 Tablespoon & $\begin{array}{l}\text { Acute ache; digestion } \\
\text { problems }\end{array}$ \\
\hline $\begin{array}{l}\text { Ranunculaceae } \\
\text { Nigella sativa L. } \\
\text { BPRN53 }\end{array}$ & Sanouj & 21 & 3.83 & $S / D$ & Raw 1 Tablespoon & $\begin{array}{l}\text { Acute ache; digestion } \\
\text { problems; intestinal comfort; } \\
\text { against bloating and diarrhea }\end{array}$ \\
\hline \multicolumn{7}{|l|}{ Rhamnaceae } \\
\hline $\begin{array}{l}\text { Zyziphus lotus L. } \\
\text { BPRN09 }\end{array}$ & Sidra, Nbeg & 21 & 3.83 & $S / D$ & $\begin{array}{l}\text { Decoction, handful quantity in } 1 \mathrm{~L} \text { of } \\
\text { water }\end{array}$ & $\begin{array}{l}\text { Acute ache; digestion } \\
\text { problems; intestinal comfort; } \\
\text { bloating }\end{array}$ \\
\hline \multicolumn{7}{|l|}{ Rosaceae } \\
\hline $\begin{array}{l}\text { Rosa damascena Mill. } \\
\text { BPRN87 } \\
\text { Verbenaceae }\end{array}$ & Elward & 5 & 0.91 & F/F or D & Hydrolats 1 cup & intestinal comfort \\
\hline $\begin{array}{l}\text { Lippia triphylla (L'Her.) Britt. } \\
\text { BPRN77 } \\
\text { Zingiberaceae }\end{array}$ & Lwiza & 18 & 3.28 & L/F or D & $\begin{array}{l}\text { Decoction, handful quantity in } 1 \mathrm{~L} \text { of } \\
\text { water }\end{array}$ & intestinal comfort \\
\hline $\begin{array}{l}\text { Elettaria cardamomum L. } \\
\text { BPRN71 }\end{array}$ & Qaâqolla & 3 & 0.55 & $S / D$ & $\begin{array}{l}\text { Decoction of powder 2-3 tablespoon } \\
\text { in } 500 \mathrm{ml}\end{array}$ & $\begin{array}{l}\text { Acute ache; digestion } \\
\text { problems, }\end{array}$ \\
\hline
\end{tabular}

F: Fresh; D: Dried; AP: Aerial part; S: Seeds; R: Roots; Epi: Epicarp; L: Leafs; F: Fruit 


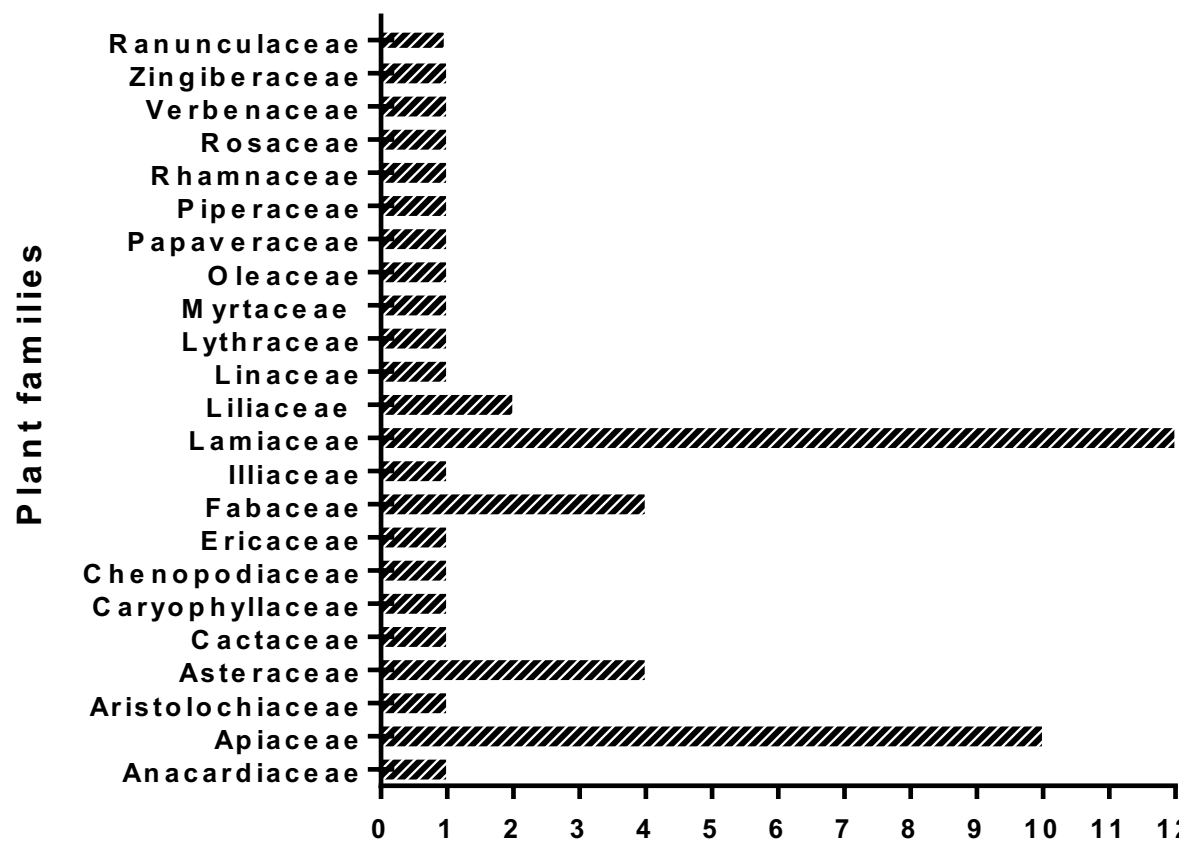

$\mathrm{Num}$ ber of citations

Figure. 2 Plant families of the reported medicinal plants

Apiaceae family consists of 3780 species in 434 genera. it's a family who encompasses a high number of plants with significant utilization to treat illnesses related to digestive, endocrine, reproductive and respiratory systems (Acimovic et al. 2015)

\section{Ethnopharmacological indexes}

The frequency of citations (RFC) values of collected plant species ranged from 0.23 to 8.41 , respectively. The most frequently used plants to treat acute digestive system problems. Their RFC values are: Foeniculum vulgare (8.58), Carum carvi (5.11), Glycyrrhiza glabra (4.56), Ammondaucus leucotrichus and Trigonella foenum-graecum (4.20), Coriandrum sativum (4.01).

Foeniculum vulgare Mill. has been known for its antiinflammatory and antinociceptive effects. Indeed, an oral administration of Foeniculum vulgare fruit methanolic extract at the dose of $200 \mathrm{mg} / \mathrm{kg}$ exhibited inhibitory effects against acute and subacute inflammatory diseases, allergic reactions type IV, and also showed a central antinociceptive effect (Choi and Hwang 2004). The antinociceptive effects of $F$. vulgare are partially mediated by histamine $\mathrm{H} 1$ and $\mathrm{H} 2$ receptors (Zendehdel et al. 2012).

The antinociceptive effect of Carum carvi (L.) has been shown for a,b-Epoxy-carvone (EC), a cyclic monoterpene found in the essential oils, that is probably associated with activation of the opioidergic system, which appears to play a role in the antinociceptive activity (da Rocha et al. 2013). In addition, the extracted oils exhibited high antiinflammatory capacity inhibiting nitric oxide (NO) release (Bourgou et al. 2019)

The anti-inflammatory and antinociceptive effects of Glycyrrhiza glabra (L.) were investigated for its aqueous and ethanolic extracts by using different pain models in swiss albino mice; both extracts exhibited antinociceptive activity by central and peripheral mechanism (Bhandage 2009)

Ammodaucus leucotrichus (Coss. \& Durieu), fruits had a strong-anti-inflammatory activity (Bonnefoy 1999), the same effect with essential oil (Mohammedi et al. 2018) and the hydroethanolic extracts of the aerial part (Ziani et al. 2019)

Trigonella foenum-graecum L. had an analgesic and anti-inflammatory activities of the seeds extract (Vyas et al. 2008). The leaves also possess antiinflammatory as well as antipyretic properties in both i.p. and p.o. administration (Ahmadiani et al. 2001). They induced an antinociceptive effect through central and peripheral mechanisms (Javan et al. 1997), alkaloid and flavonoid content of fenugreek seeds can be responsible for antinociception and anti-inflammatory effects, respectively (Mandegary et al. 2012). 
Coriandrum sativum $\mathrm{L}$. has a modulator effect on pain (Taherian et al. 2012), the total extract, polyphenols extract, and essential oil of coriander had a significant analgesic effect. (Haidari et al. 2011).

Plant parts used, mode of preparation and administration

Dried plants were the most used compared to fresh plants $(61 \%$ versus $39 \%)$. The aerial part was the most used plant part with a percentage of $34 \%$, followed by seeds $(28 \%)$, leaves $(14 \%)$, roots $(8 \%)$, fruits $(6 \%)$, bulbs $(4 \%)$, epicarps $(4 \%)$ and finally umbels (2\%) (Figure 3 ).

The decoction is the primary preparation made with a percentage of $(50 \%)$, followed by powder $(23 \%)$, hydrolats $(15 \%)$, juice $(6 \%)$, raw $(5 \%)$, and finally infusion (1\%) (Figure 4).

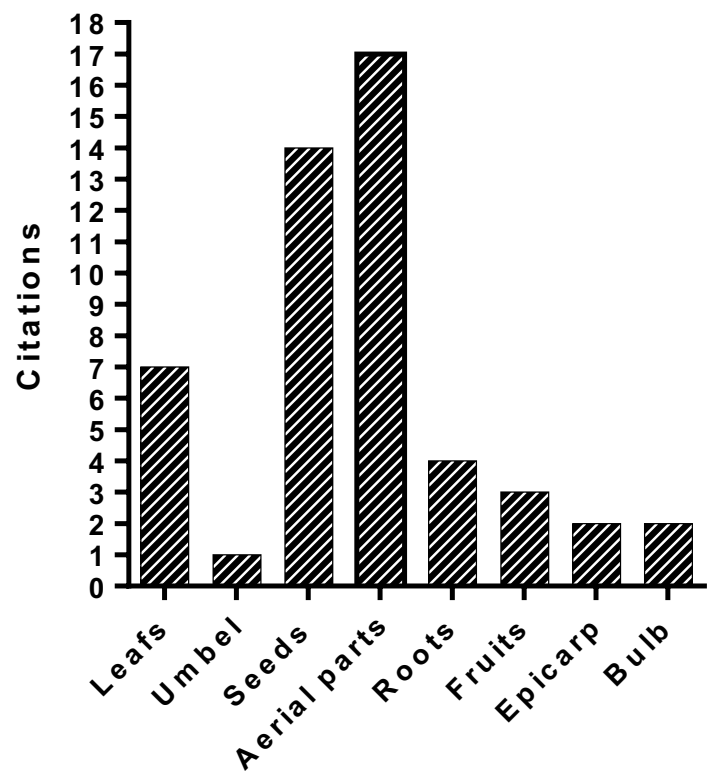

Figure 3. Plant parts used in remedy preparation

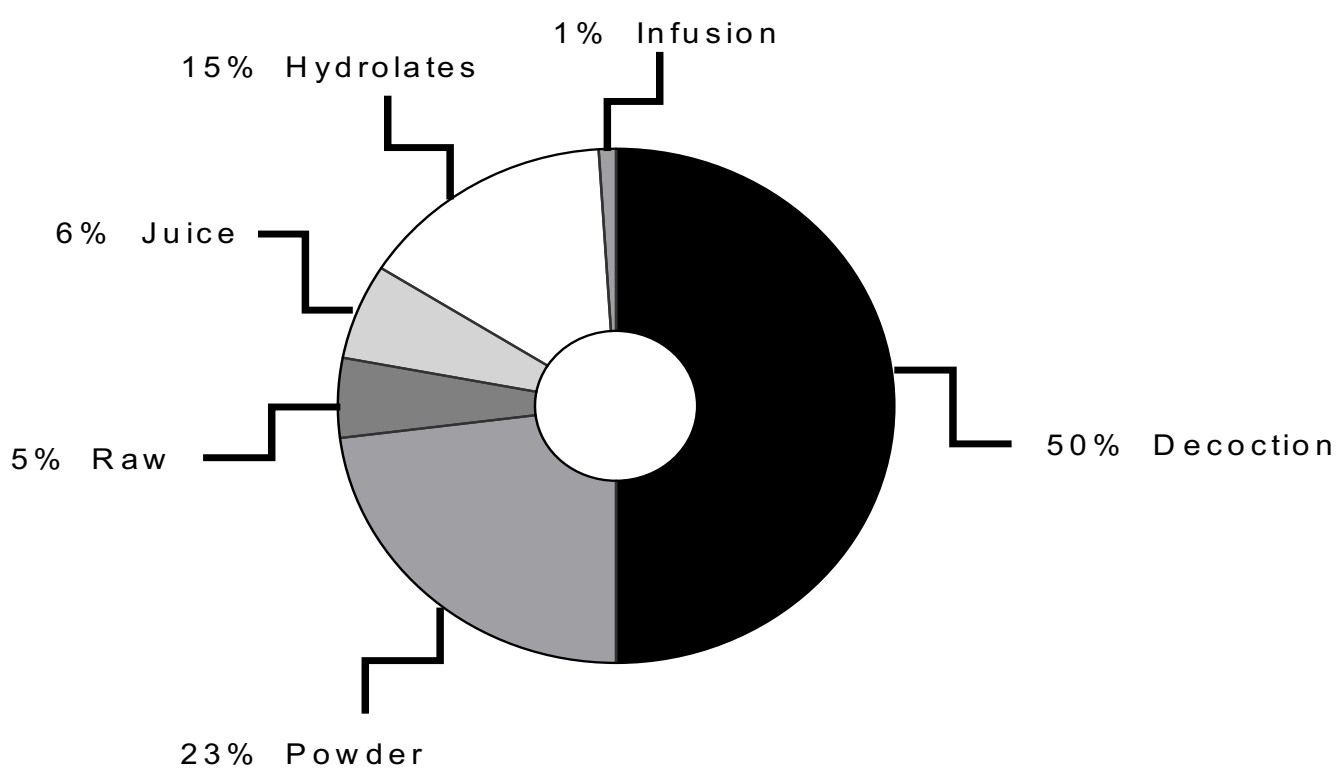

Figure 4. Plant mode of preparation (\%) 
Acute digestive system problems

According to the feedback from the interviewed population, the acute digestive system problems concerned six categories: Acute ache, digestion problems; intestinal comfort; bloating, diarrhea, and constipation.

From the 50 plants inventoried, the most utilization was for acute aches $(94 \%)$ and digestion problem (84\%) followed by intestinal comfort $(50 \%)$ and finally, diarrhea and constipation (16 and 4\% consequently).

The multiple utilization of a single plant in different categories is from the fact that those categories are related in a manner that if you are attending a digestive system problem, you will probably manifest one or more of those categories at the same time.

\section{Conclusions}

This survey is the first work that explicitly highlights the knowledge of acute digestive system problems in the region of Fez-Meknes in Morocco. The interviewers showed confidence and trust when informing about their successful use of the medicinal plant as a first choice for the treatment and were very satisfied. Detailed information about the 50 plants inventoried was carefully recorded to preserve accurately the knowledge about the procedures in the use of these plants. This variety of medicinal plants used to deal with acute digestive system problems shows clearly the importance of plants in the healthcare system in Morocco. The recorded information in the present study may be used as baseline data for future scientific investigations.

\section{Declarations}

Ethics statement and consent to participants: All participants provided prior informed consent.

\section{List of abbreviations: N/A}

Ethics approval and consent to participate: Before conducting interviews, prior informed consent was obtained from all participants. No further ethics approval was required.

Funding: The authors received no financial support for this research.

Conflict of interest: The authors declare that they have no conflict of interest.

Authors' contributions: All the authors approved the final manuscript after revision.

\section{Acknowledgments}

This work is part of the European Union (EU) international staff exchange project H2020-MSCARISE-2016-734759 (VAHVISTUS).
A massive thanks to all traditional health practitioners in the Region of Fez-Meknes for their contribution, time, and help.

\section{Literature cited}

Acimovic M, Kostadinovic L, Popovic S, Dojcinovic N. 2015. Apiaceae seeds as functional food. Journal of Agricultural Sciences, Belgrade. 60(3):237-246. doi:10.2298/JAS1503237A.

ACOG. 2014. The American College of Obstetricians and Gynecologists. The American College of Obstetricians and Gynecologists. [accessed 2019 Aug 3]. https://www.acog.org/Patients/FAQs/Problems-ofthe-Digestive-System?IsMobileSet=false.

Ahmadiani A, Javan M, Semnanian S, Barat E, Kamalinejad M. 2001. Anti-inflammatory and antipyretic effects of Trigonella foenum-graecum leaves extract in the rat. Journal of Ethnopharmacology. 75(2):283-286. doi:10.1016/S0378-8741(01)00187-8.

Bhandage A. 2009. Evaluation of Antinociceptive Activity of Roots of Glycyrrhiza glabra Linn. Journal of Pharmacy Research.(5):5.

Bonnefoy Y. 1999. Dictionnaire des mythologies - 1 de Yves Bonnefoy - Editions Flammarion p. 546 b. [accessed 2019 May 20]. https://editions.flammarion.com/Catalogue/mille-etune-pages/dictionnaire-des-mythologies-1.

Bourgou S, Rebey IB, Dakhlaoui S, Msaada K, Tounsi MS, Ksouri R, Fauconnier M-L, HamrouniSellami I. 2019. Green extraction of oil from Carum carvi seeds using bio-based solvent and supercritical fluid: Evaluation of its antioxidant and antiinflammatory activities. Phytochemical Analysis. 0(0). doi:10.1002/pca.2864. [

Budha-Magar S, Bhandari P, Kumar Ghimire S. 2020. Ethno-medicinal survey of plants used by Magar (Kham) community, Rolpa district, Western Nepal. Ethnobotany Research and Applications. 19. doi:10.32859/era.19.18.1-29.

Choi E-M, Hwang J-K. 2004. Antiinflammatory, analgesic and antioxidant activities of the fruit of Foeniculum vulgare. Fitoterapia. 75(6):557-565. doi:10.1016/j.fitote.2004.05.005.

Fennane, Ibn Tattou. 2012. Statistiques et commentaires sur l'inventaire actuel de la flore vasculaire du Maroc. :10.

Fennane M, Tattou MI, Mathez J. 1999. Flore pratique du Maroc: manuel de détermination des plantes vasculaires. Pteridophyta, Gymnospermae, Angiospermae (Lauraceae-Neuradaceae). Institut scientifique.

Haidari F, Seyed-Sadjadi N, Taha-Jalali M, Mohammed-Shahi M. 2011. The effect of oral 
administration of Carum carvi on weight, serum glucose, and lipid profile in streptozotocin-induced diabetic rats. Saudi medical journal. 32(7):695-700.

Jamaleddine M, El Oualidi J, Taleb MS, Thévenin T, El Alaoui-Faris FE. 2017. Inventaire et état de conservation des plantes aromatiques et médicinales (PAM) au Maroc. Phytothérapie. 15(3):114-122. doi:10.1007/s10298-017-1131-2.

Javan M, Ahmadiani A, Semnanian S, Kamalinejad M. 1997. Antinociceptive effects of Trigonella foenum-graecum leaves extract. Journal of Ethnopharmacology. 58(2):125-129. doi:10.1016/S0378-8741(97)00089-5.

Malinga GM, Baana K, Rutaro K, Atube F, Opoke R, Opika-Opoka H, Oryema C. 2020. An ethnobotanical study of plants used for the treatment of malaria in Budondo sub-county, Eastern Uganda. Ethnobotany Research and Applications. 19. doi:10.32859/era.19.04.1-15.

Mandegary A, Pournamdari M, Sharififar F, Pournourmohammadi S, Fardiar R, Shooli S. 2012. Alkaloid and flavonoid rich fractions of fenugreek seeds (Trigonella foenum-graecum L.) with antinociceptive and anti-inflammatory effects. Food and Chemical Toxicology. 50(7):2503-2507. doi:10.1016/j.fct.2012.04.020.

Mechchate $H$, Es-safi I, Jawhari $F$ zahra, Bari A, Grafov A, Bousta D. 2020. Ethnobotanical survey about the management of diabetes with medicinal plants used by diabetic patient in Region of FezMeknes, Morocco. Ethnobotany Research and Applications; $\quad$ Vol $19 \quad$ (2020). doi:10.32859/era.19.12.1-28.

Mohammedi $\mathrm{H}$, Idjeri-Mecherara S, Menaceur F, Azine K, Hassani A. 2018. Chemical Compositions of Extracted Volatile Oils of Ammodaucus leucotrichus L. Fruit from Different Geographical Regions of Algeria With Evaluation of its Toxicity, Anti-inflammatory and Antimicrobial Activities. Journal of Essential Oil Bearing Plants. 21(6):15681584. doi:10.1080/0972060X.2018.1559102.

Monographie Générale. 2015. La Région de FèsMeknès. ROYAUME DU MAROC Ministère de I'Intérieur Direction Générale des Collectivités Locales.

da Rocha ML, Oliveira LEG, Patrício Santos CCM, de Sousa DP, de Almeida RN, Araújo DAM. 2013.
Antinociceptive and anti-inflammatory effects of the monoterpene $\alpha, \beta$-epoxy-carvone in mice. J Nat Med. 67(4):743-749. doi:10.1007/s11418-012-0738-8.

Sidhu K, Kaur J, Kaur G, Pannu K. 2007. Prevention and Cure of Digestive Disorders Through the Use of Medicinal Plants. Journal of Human Ecology. 21(2):113-116.

doi:10.1080/09709274.2007.11905959.

Taherian AA, Vafaei AA, Ameri J. 2012. Opiate System Mediate the Antinociceptive Effects of Coriandrum sativum in Mice. Iran J Pharm Res. 11(2):679-688.

Tardío J, Pardo-de-Santayana M. 2008. Cultural Importance Indices: A Comparative Analysis Based on the Useful Wild Plants of Southern Cantabria (Northern Spain)1. Econ Bot. 62(1):24-39. doi:10.1007/s12231-007-9004-5.

Uritu CM, Mihai CT, Stanciu G-D, Dodi G, AlexaStratulat $\mathrm{T}$, Luca A, Leon-Constantin M-M, Stefanescu R, Bild V, Melnic S, et al. 2018. Medicinal Plants of the Family Lamiaceae in Pain Therapy: A Review. Pain Research and Management. doi:https://doi.org/10.1155/2018/7801543.

Vyas S, Agrawal RP, Solanki P, Trivedi P. 2008. Analgesic and anti-inflammatory activities of Trigonella foenum-graecum (seed) extract. Acta Poloniourm Pharmacologiorum 65(4)4:473-476.

World Health Organization. 2002. The WHO strategy for traditional medicine: Review of the global situation and strategy implementation in the Eastern Mediterranean Region. [accessed 2019 May 20]. https://apps.who.int/iris/handle/10665/122025.

Zendehdel M, Taati M, Amoozad M, Hamidi F. 2012. Antinociceptive effect of the aqueous extract obtained from Foeniculum vulgare in mice: the role of histamine $\mathrm{H} 1$ and $\mathrm{H} 2$ receptors. Iranian Journal of Veterinary Research. 13(2):100-106. doi:10.22099/ijvr.2012.98.

Ziani BEC, Rached W, Bachari K, Alves MJ, Calhelha RC, Barros L, Ferreira ICFR. 2019. Detailed chemical composition and functional properties of Ammodaucus leucotrichus Cross. \& Dur. and Moringa oleifera Lamarck. Journal of Functional Foods. 53:237-247. doi:10.1016/j.jff.2018.12.023. 


\title{
Annex A : Ethnobotanical survey
}

\author{
Université Sidi Mohamed Ben Abdellah- Fès \\ Modèle-Questionnaire d'Enquête Ethno-pharmacologique \\ Prof D. BOUSTA
}

\begin{abstract}
Fiche $\mathrm{n}^{\circ}$ :
Classement (par thème, ordre alphabétique, région ou autre) :

Documents annexées (photos, diapositives, herbiers...) :
\end{abstract}

\section{1-RENSEIGNEMENT SUR L'INFORMATEUR}

- Sexe : Femme........................Homme

-Age : $18-24 \square$ 25-34 $\square$ 35-49 $\square$ 49-65 $\square 65 \geq \square$

- Origine ethnique :

- Commune:.

- Niveau d'instruction : Néant $\square$ Primaire $\square$ Secondaire $\square$ Universitaire $\square$

- Situation familiale : Célibataire $\square$ Marié $\square$

- Métier : Herboriste.

Guérisseur

Autres.

Comment vous avez eu ces connaissances ? Lui-même $\square$ Expérience des autres $\square$ Herboriste $\square$

Livres $\square$ Occasionnellement $\square$ Autres $\square$

- Exerce t-il d'autre pratique médicinale traditionnelle ? Si oui, les quels ?

- Que préférez-vous ? les soins médicaux $\square$ Les soins phytothérapeutiques $\square$

-Pourquoi?

-Qui consultez-vous en cas de maladie ? : Personnel médical $\square$ Guérisseur $\square$

-Autres :

\section{2- RENSEIGNEMENT SUR LE PRATICIEN}

Nom :

Prénom

Age :

Lieu de Naissance :

ou origine régionale:

Lieu d'établissement :

Appartenance ethnique

Niveau d'instruction :....

Depuis quand exerce t'il le métier de guérisseur?

Qui l'a formé.

S'il s'agit d'un praticien lettré, quels livres de médecine arabe possède-t-il ? Est 'il polyvalent ou exerce une spécialité ?......

Est -il spécialisé dans le traitement d'une maladie ?

A-t-il formé quelqu'un?

\section{2 - RENSEIGNEMENT SUR LE PRODUIT}

2-1 Simple :

2.1.1 - Caractéristiques de l'habitat de la plante

Sol :

Relief : 
Climat :

Action anthropique :

Aire de répartition :

2.2 - Systématique

-Famille:

-Genre:

-Espèce:

2.3 Dénominations locales :

Toxicité, effets secondaires : toxicité pour l'homme et/ou le bétail, risque et effets indésirables :

Dose......

Mode de préparation :

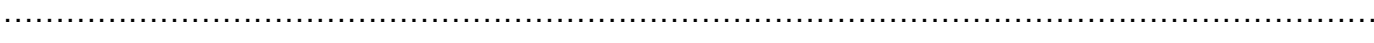

Autres $\square$ :

Posologie :

Pour les nourrissons : 1 fois/jour $\square$ 2fois/jour $\square$ 3fois/jour $\square$ Autres $\square$ :

Pour les enfants : 1 fois/jour $\square$ 2fois/jour $\square$ 3fois/jour $\square$ Autres $\square$ :

Pour les Adultes : 1fois/jour $\square$ 2fois/jour $\square$ 3fois/jour $\square$ Autres $\square:$

Pour les personnes âgées : 1fois/jour $\square$ 2fois/jour $\square$ 3fois/jour $\square$ Autres $\square$ :

Durée d'utilisation (durée de traitement) :

Un jour $\square$ Une semaine $\square$ Un mois $\square$ Jusqu'à la guérison $\square$

Mode d'administration :

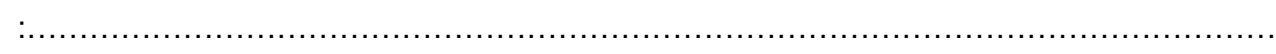

Associations :

Autres informations :

2-1 Plante : (Seule)

Parties utilisées: Tige $\square$ Fleurs $\square$ Fruits $\square$ Graine $\square$ Écorce $\square$ Rhizome $\square$ Bulbe $\square$ Latex $\square$ 
Feuilles $\square$ Plante entière $\square$ Autres combinaisons $\square$ :

État de la plante : Fraîche $\square$ Desséché $\square$

Forme d'emploi : Tisane $\square$ Poudre $\square$ Huiles essentielles $\square$

Lieu de récolte : Lieu d'acquisition:.

Produit : local $\square$ sauvage $\square$ local $\square$ cultivé $\square$ importé $\square$

Autres :

Conditions et modalités de la récolte : (saison, période du jour, etc).

Autres utilisations médicinales :

\section{2-2 Mixte : (recette)}

Parties utilisées : Tige $\square$ Fleurs $\square$ Fruits $\square$ Graine $\square$ Écorce $\square$ Rhizome $\square$ Bulbe $\square$

Feuilles $\square$

Plante entière $\square \quad$ Autres combinaisons $\square$ :

État de la plante : Fraîche $\square$ Desséché $\square$

Lieu de récolte des plantes

Lieu d'acquisition :

Produit: local $\square$ sauvage $\square$ local cultivé $\square \quad$ importé $\square$

Autres :

Conditions et modalités de la récolte : (saison, période du jour, etc).

Traitement reçu par le produit : (séchage, pulvérisation)

Indications (si celles-ci varient en fonction des parties, faire une fiche pour chaque partie).

Autres utilisations médicinales : 